\title{
Genetic Improvement of Berseem (Trifolium alexandrinum) in India: Current Status and Prospects
}

\author{
Tejveer Singh $^{1}{ }^{*}$, A. Radhakrishna ${ }^{1}$, D. Seva Nayak ${ }^{1}$ and D.R. Malaviya ${ }^{2}$ \\ ${ }^{1}$ ICAR- Indian Grassland and Fodder Research Institute, Jhansi-284 003, India \\ ${ }^{2}$ ICAR- Indian Institute of Sugarcane Research, Lucknow - 226 002, India \\ *Corresponding author
}

\section{A B S T R A C T}

Berseem, a nitrogen-fixing, annual, multicut forage crop cultivated around 2 million hectares areas of northern, central and eastern parts of India. Berseem has variability for

\begin{tabular}{|l|}
\hline Ke y w or d s \\
Cross \\
incompatibility, \\
Genomic resources, \\
Gene pool, \\
$\begin{array}{l}\text { Polyploidy, Wide } \\
\text { hybridization }\end{array}$ \\
\hline Article Info \\
\hline $\begin{array}{l}\text { Accepted: } \\
\text { 26 December 2018 } \\
\text { Available Online: } \\
\text { 10 January 2019 }\end{array}$ \\
\hline \hline
\end{tabular}
pollination behavior however variation for morphological and agronomic traits are scare, perhaps, because of initially introduction of crop with narrow genetic base. Genetic variability have been fortified through introduction of exotic materials, intra-interspecific hybridization, induction of polyploidy and mutation. ICAR-Indian Grassland and Fodder Research Institute maintain $>900$ accessions of Trifolium spp. Different genetic improvement programmes in India resulted with development of $>15$ cultivars apart from unique agro-morphological variants. Affinity of Berseem was tested with other species and suitable donors for introgression of genes especially for biotic stress were identified. By adopting embryo rescue technique, wide crosses of Berseem with $T$. constantinopolitanum, $T$. apertum, $T$. resupitanum and $T$. vessiculosum successfully developed and genes for biotic stresses and agro-morphological traits were incorporated. Longer duration, an important agronomic trait in Indian condition, has been induced through induction of mutation by physical mutagens. Induction of autopolyploidy by using coltchicine treatment made major breakthrough in berseem breeding in India by the development of high biomass producing cultivars. The future breeding strategies contemplate to intensification of gene pool through exotics from the centre of origin, increase of variability, development of genomic resources, development of inbreds, remodeling of breeding procedure as substantial points.

\section{Introduction}

The genus Trifolium from the tribe Trifolieae of the family Leguminosae (Fabaceae) is important for its agricultural value. A few of the 237 species of this large genus have actually been cultivated to date (Zohary and Heller, 1984), out of which 25 species are agriculturally important as cultivated and pasture crops (Lange and Schifino-Wittmann, 2000). Berseem or Egyptian clover (Trifolium alexandrinum $2 \mathrm{n}=2 \mathrm{x}=16$ ) is commonly cultivated as winter annuals in the tropical and subtropical regions. Berseem, introduced in India from Egypt in 1904, started cultivation as a rotational crops at government cattle 
farm, since 1910 its cultivation was taken up by cultivators (Das Gupta, 1943). Berseem has been established as one of the best Rabi (winter season) fodder crop in entire North West Zone, Hill Zone and part of Central and Eastern Zone of the country (Mehta and Swaminathan, 1965; Singh, 1988), occupy more than two million hectare (Pandey et al., 2011). Berseem are popular due to its multicut (4-8 cuts) nature, providing fodder for a long duration (November to May), very high quantum of green fodder (85 t/ha) and better quality of fodder (20\% crude protein), high digestibility (up to $65 \%$ ) and palatability.

\section{Pollination behavior}

Understanding the natural mating behavior (self- or cross-pollination) is important for designing a suitable breeding strategy for genetic improvement of crop. The Berseem crop is a dilemma with regard to its self and cross pollination.

In Indian conditions, a number of reports on pollination in Berseem suggest that this crop is not self-sterile but tripping is essential for a good seed-set (Chowdhury et al., 1966, Roy et $a l$. , 2005). The crop is predominantly selfpollinated and shows wide diversity for self fertility and population with self compatible and self pollinating, self compatible requiring tripping, self incompatible with broad genetic base and self incompatible with narrow genetic base have been identified (Dixit et al., 1988). Roy et al., (2005) indicated considerable variation between different populations of Berseem for self-compatibility, together with a requirement of tripping for pollination and seed set, even in selfcompatible lines. Extant of natural cross pollination was reported up to $4.73 \%$ by Beri et al., (1985a) and seed setting were higher under un-caged condition against caged condition due to tripping mechanism done by honey bees (Beri et al., 1985b)

\section{Germplasm management}

In India, National Bureau of Plant Genetic Resources (NBPGR), New Delhi is the nodal organization for exchange, quarantine, collection, conservation, evaluation and the systematic documentation of plant genetic resources. It has introduced $>500$ accessions of Trifolium spp from different countries and maintained in long term storage conditions. The Indian Grassland and Fodder Research Institute (IGFRI), Jhansi is a National Active Germplasm Site for the systematic management and utilization of germplasm wealth of forage crops including agro-forestry trees maintains >900 accessions of Trifolium spp. For effective utilization and maintenance of conserved germplasm, IGFRI has catalogue the information on different qualitative, quantitative and origin place of all 594 accessions. To assist the utilization of Berseem germplasm by curators/scientists throughout the international plant genetic resources network, IGFRI has developed descriptor list of Berseem (Roy et al., 2009). Many of the Berseem germplasm having unique characteristics have been generated (Singh et al., 2017) and registered at NBPGR, New Delhi (Table 1).

\section{Breeding approches}

Berseem is an introduced crop in India and one of the most important drawbacks in genetic improvement of Berseem is lack of genetic variability (Verma and Mishra, 1995; Roy et al., 2004; Malaviya et al., 2005; Malaviya et al., 2007). Variability in the existing gene pool of Berseem has been induced in through mutation, polyploidization and interspecific hybridization. Different genetic improment programmes by utilizining breeding approches like selection, polyploidy and mutation leads to the development of $>15$ varieties for different berseem growing regions of India (Table 2). High biomass 
production potential alongwith extended growth period and resistance to biotic stresses specially root rot and stem rot are the main target traits has to be improved genetically.

\section{Inter-specific hybridization}

Initially, the aim of interspecific hybridization was to clarify the closest relatives of $T$. alexandrinum. T. alexandrinum $(2 n=16)$ was successfully hybridized with $T$. berytheum $(2 n$ $=16)$ and $T$. salmoneum $(2 n=16)$ and found the most probable parent. Recently, efforts has been put into using this approach with the aim of improving $T$. alexandrinum's resistance to biotic and abiotic stresses, tolerance to soil alkalinity and length of the vegetative period. Genes for wide scale adaptability and disease resistance widely distributed in several wild species of Trifolium (Table 3) could not be incorporated into the present day cultivars because of interspecific incompatibility barrier which are common among other Trifolium species also. Embryo culture has been effectively used in developing interspecific hybrids of Berseem with Trifolium apertum (Malaviya et al., 2004), $T$. constantinopolitanum (Roy et al., 2004), T. resupinatum (Kaushal et al., 2005) and $T$. vesiculosum (Kaur et al., 2017). Progenies of interspecific hybrids showed introgression of various desirable traits, including late flowering and resistance to root rot and stem rot diseases.

\section{Ploidy manipulation}

A major breakthrough in Berseem breeding in India was achieved through induction of polyploidy. The work on polyploidyzation of Berseem genome was started with the aim to induce grater leaf and stem size (Mehta and Swaminathan, 1957; Sikka et al., 1959). Autotetraploid induced by using coltchicine treatment, and selection at tetraploid level resulted the development of first Berseem variety 'Pusa Giant' with more fodder production and good regeneration capacity, uniform and higher yield throughout the season than diploid varieties released for general cultivation in India (Metha and Swaminathan, 1965). Another big achievement in polyploidy breeding was achieved at IGFRI, Jhansi by developing an autotetraploid variety namey 'Bundel Berseem-3' through colchiploidy followed by recurrent single plant selection followed with mass selection. It is released for north east zone, Bihar Orissa, WB and eastern UP.

\section{Mutation breeding}

Major constraints in genetic improvement of Berseem are narrow genetic base of the crop coupled with cross incompatibility barriers (Malaviya et al.,). Efforts have been made to generate variation in the existing gene pool through mutation by using physical or chemical mutagens (Sindhu and Mahindiratta 1976: Jatasra et al., 1980; Shukla and Tripathi, 1984). Major success was achieved by induction of longer duration mutant in Mescavi variety through gamma ray treatment (Sohoo et al., 1985). These longer duration mutant in the form of BL-22 a variety released in 1988 for temperate and north west zone; BL-180 released in 2006 for cultivation in north-west zone of India. Longer duration (flowering in May-June) is the important agronomic trait in Indian condition. Incorporation of this trait in Berseem variety for additional cut of green fodder during the scarcity period of summer months may be achieved.

\section{Biotic and abiotic stress tolerance}

Berseem cultivars are susceptible to diseases like root rot (Rhizoctonia solani and Fusarium semitactum), stem rot (Scferotinia trifoliorum), leaf blight (Epicocum sp.) powdery mildew (Oidium sp.) and downy mildew (Perenospora trifolif) (Bhaskar et al., 2002). 
Table.1 Novel genetic stock of Berseem (Trifolium alexandrinum) registered with NBPGR, New Delhi

\begin{tabular}{|l|l|l|l|l|}
\hline S.no. & Trait & Ploidy level & Year & INGR number \\
\hline $\mathbf{1}$ & Purple leaf and flower & Diploid $(2 n=2 X=16)$ & 2005 & NGR05017 \\
\hline $\mathbf{2}$ & Pentafoliate Berseem Penta 1 & Diploid $(2 n=2 X=16)$ & 2009 & INGR 09045 \\
\hline $\mathbf{3}$ & Pentafoliate & Tetraploid $(2 n=4 X=32)$ & 2012 & INGR 12010 \\
\hline $\mathbf{4}$ & Black seeded & Diploid $(2 n=2 X=16)$ & 2012 & INGR 12009 \\
\hline $\mathbf{5}$ & Self incompatible & Tetraploid $(2 n=4 X=32)$ & 2012 & INGR 12011 \\
\hline $\mathbf{6}$ & Self compatible & Diploid $(2 n=2 X=16)$ & 2012 & INGR 12012 \\
\hline $\mathbf{7}$ & Blackseeded pentafoliate & Diploid $(2 n=2 X=16)$ & 2016 & INGR 15026 \\
\hline
\end{tabular}

Table.2 Berseem varieties released/notified in India

\begin{tabular}{|c|c|c|c|c|c|}
\hline $\begin{array}{l}\text { S. } \\
\text { No. }\end{array}$ & Variety & $\begin{array}{l}\text { Breeding } \\
\text { method }\end{array}$ & $\begin{array}{l}\text { Year of } \\
\text { release/ } \\
\text { notification }\end{array}$ & $\begin{array}{l}\text { Institution } \\
\text { responsible for } \\
\text { the development }\end{array}$ & Area of adaptation \\
\hline 1. & Mescavi & Selection & 1975 & CCS HAU, Hisar & Entire growing area \\
\hline 2. & Pusa Giant & $\begin{array}{l}\text { Polyploidy } \\
\text { breeding }\end{array}$ & 1975 & IARI & Entire growing area \\
\hline 3. & BL 1 & Selection & 1978 & PAU, Ludhiana & Punjab, H.P., Jammu \\
\hline 4. & Wardan & Selection & 1982 & IGFRI, Jhansi & Entire growing area \\
\hline 5 & $\begin{array}{l}\text { Jawahar } \\
\text { Berseem } 1(\mathrm{JB} \\
\text { 1) }\end{array}$ & Selection & 1981 & JNKVV, Jabalpur & $\begin{array}{l}\text { Central India, central and north } \\
\text { western zones }\end{array}$ \\
\hline 6 & BL-10 & $\begin{array}{l}\text { Mutation } \\
\text { breeding }\end{array}$ & 1985 & PAU, Ludhiana & Punjab, Haryana, H.P., Jammu \\
\hline 7. & BL 22 & $\begin{array}{l}\text { Mutation } \\
\text { breeding }\end{array}$ & 1988 & PAU, Ludhiana & $\begin{array}{l}\text { Sub-temperate, hill regions of } \\
\text { North India }\end{array}$ \\
\hline 8. & BL 2 & Selection & 1989 & PAU, Ludhiana & $\begin{array}{l}\text { Punjab, Haryana, H.P., Jammu, } \\
\text { Western UP, Uttrakhand }\end{array}$ \\
\hline 9. & UPB 10 & $\begin{array}{l}\text { Composite } \\
\text { Selection }\end{array}$ & 1993 & $\begin{array}{l}\text { GBPUAandT, } \\
\text { Pantnagar }\end{array}$ & North-west India \\
\hline 10. & $\begin{array}{l}\text { Bundel } \\
\text { Berseem } 2\end{array}$ & Mass Selection & 1997 & IGFRI, Jhansi & Central, North-west zone \\
\hline 11. & $\begin{array}{l}\text { Bundel } \\
\text { Berseem } 3\end{array}$ & $\begin{array}{l}\text { Polyploidy } \\
\text { breeding }\end{array}$ & 2001 & IGFRI, Jhansi & North-east, Eastern region \\
\hline 12. & JB-5 & $\begin{array}{l}\text { Polyploidy } \\
\text { breeding }\end{array}$ & 2005 & JNKVV, Jabalpur & Central, North-west zone \\
\hline 13. & BL 42 & $\begin{array}{l}\text { Mutation } \\
\text { breeding }\end{array}$ & 2003 & PAU, Ludhiana & North-west India \\
\hline 14. & BL 180 & $\begin{array}{l}\text { Mutation } \\
\text { breeding }\end{array}$ & 2006 & PAU, Ludhiana & North-west India \\
\hline 15 & $\begin{array}{l}\text { Hisar Berseem } \\
1 \text { (HFB 600) }\end{array}$ & Selection & 2006 & CCS HAU, Hisar & North-west India \\
\hline 16. & JBSC-1 & Selection & 2017 & IGFRI, Jhansi & Central, North-west zone \\
\hline
\end{tabular}


Table.3 Desirable characters in Berseem ecotypes and wild Trifolium species

\begin{tabular}{|c|c|c|c|c|}
\hline Species & Gene pool & $\begin{array}{l}\text { Chromosome } \\
\text { Number }(2 n)\end{array}$ & Desirable characters & References \\
\hline $\begin{array}{l}\text { T. alexandrinum } \\
\text { ecotype Mescavi }\end{array}$ & Primary & $2 n=16$ & $\begin{array}{l}\text { Annual, multicut, highly } \\
\text { productive, crude protein, high } \\
\text { digestibility and palatability, basal } \\
\text { branching }\end{array}$ & $\begin{array}{l}\text { Malaviya et al., } \\
2004\end{array}$ \\
\hline $\begin{array}{l}\text { T. alexandrinum } \\
\text { ecotype Fahli }\end{array}$ & Primary & $2 n=16$ & 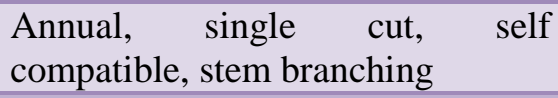 & Singh et al., 2015 \\
\hline $\begin{array}{l}T . \quad \text { alexandrinum } \\
\text { ecotype Saidi }\end{array}$ & Primary & $2 n=16$ & $\begin{array}{l}\text { Annual, 2-3 cut, stem and basal } \\
\text { branching }\end{array}$ & \\
\hline T. berytheum & Secondary & $2 n=16$ & - & $\begin{array}{l}\text { Putiyevksy and } \\
\text { Katznelson, } 1973\end{array}$ \\
\hline T. salmoneum & Secondary & $2 n=16$ & - & $\begin{array}{l}\text { Putiyevksy and } \\
\text { Katznelson, } 1973\end{array}$ \\
\hline T. apertum & Secondary & $2 n=16$ & $\begin{array}{l}\text { Annual, profuse basal branching, } \\
\text { late flowering, resistance against } \\
\text { root rot and stem rot, high protein } \\
\text { content }\end{array}$ & $\begin{array}{l}\text { Putiyevksy and } \\
\text { Katznelson, 1973; } \\
\text { Malaviya et al., } \\
2004\end{array}$ \\
\hline T. meironense & Secondary & $2 n=16$ & & $\begin{array}{l}\text { Putiyevksyand } \\
\text { Katznelson, } 1973\end{array}$ \\
\hline T. resupinatum & Tertiary & $2 n=16$ & $\begin{array}{l}\text { Root rot and stem rot resistance, } \\
\text { soil alkalinity tolerance }\end{array}$ & $\begin{array}{l}\text { Bhaskar et al., } \\
\text { 2002; Kaushal et } \\
\text { al., } 2005\end{array}$ \\
\hline $\begin{array}{l}T . \\
\text { constantinopolitanum }\end{array}$ & Tertiary & $2 n=16$ & $\begin{array}{l}\text { Profuse basal branching, resistance } \\
\text { against root rot and stem rot }\end{array}$ & Roy et al., 2004 \\
\hline T. vesiculosum & Tertiary & $2 n=16$ & Lateness, disease resistance & $\begin{array}{l}\text { Malaviya et al., } \\
2004\end{array}$ \\
\hline
\end{tabular}

Berseem cultivar 'Bundel Berseem-3' developed through polyploidy is moderately tolerant to the root rot and stem rot disease. Beseem is highly sensitive to drought conditions as it decreased plant fresh and dry matter yield (Sevanayak et al., 2017).

Berseem cultivars and inbreds derived from interspecific hybrids were evaluated under drought stress condition and drought tolerance lines identified (Shipra et al., 2010, Sevanayak et al., 2017). Further, different species of Trifolium from secondary and tertiary gene pool are known to be resistance against various biotic and abiotic stresses (Table 3) and could be utilized for introgression of desirable genes by utilizing advanced molecular techniques.

\section{Biotechnological approach}

Biotechnological approaches offering alternative and effective tools for genetic improvement of crop plants. Utilization of biotechnological approaches in genetic improvement by genetic transformation and other means requires efficient method for plant regeneration via tissue culture using different parts of plant. Protocol for in vitro plant regeneration from meristematic tissue and the establishment of regenerable callus culture have been developed in Berseem and related species viz., Trifolium glomeratum, $T$ apertum, $T$ resupinatum (Kaushal et al., 2004, Kaushal et al., 2006). Embryo rescue technique has been effectively utilized to overcome the problems of post fertilization 
barriers in interspecific crosees of Berseem with Trifolium apertum, $T$. constantinopolitanum, $T$. resupinatum and $T$. vesiculosum (Malaviya et al., 2004; Kaushal et al., 2005; Roy et al., 2004; Kaur et al., 2017). Limited availability of genomic resources in Berseem hampered the utilization of molecular markers in genetic improvement programme. Therefore, molecular markers were developed and validated in Berseem (Verma et al., 2017, Chandra 2011). Genetic diversity in Berseem and related Trifolium species were studied by using isozymes (Malaviya et al., 2005) and molecular markers (Kalia et al., 2009).

\section{Future prospects and conclusion}

Berseem being an important forage crop providing nutritional security to the animals by producing high quantum of quality green forage, also contributing to the sustainability of rice-wheat cropping system. Being an introduced crop in India, genetic improvement in this crop is hampered by narrow genetic base and lack of variability in desirable traits. Further introduction of germplasm from its origin place, development of interspecific hybrids and induction of mutations will further contribute in broadening the genetic base of berseem. Desirable variants developed through interspecific hybridization and mutation could be utilized in development of improved cultivars. Development of inbreds and further establishment of heterotic pool will help in development high biomass producing synthetic and composite population and hybrids. There is a scope to further strengthen the genomic resources by developing more SSR markers, molecular linkage map and mapping of forage quality and biomass contributing traits which could be utilized to speed up conventional breeding programme going on in different research institutes/universities.

\section{References}

Badr A, El-Shazly HH, Watson LE, 2008. Origin and ancestry of Egyptian clover (Trifolium alexandrinum L.) as revealed by AFLP markers. Genet Resour Crop Evol 55:21-31

Bakheit B.R. (1989) Pollination and seed setting in different genotypes of Egyptian clover

Berseem (Trifolium alexandrinum L.) Assiut Journal of Agricultural Sciences. 20: $1,199-208$

Bakiheit. B.R. (1996) Development of a New Multifoliate Strain of Berseem Clover (Trifolium alexandrinum L.) in Egypt, Journal of Agronomy and Crop Science. 177, 139-141.

Beri SM, M. S. Sohoo M. S., H. L. Sharma, HL (1985a) Estimates of natural cross pollination in Egyptian clover. Euphytica, 34 (1): 147-151

Beri SM, M. S. Sohoo, H. L. Sharma (1985b). Mode of pollination and seed setting in Egyptian clover. Euphytica, 34(3): 745750.

Bhaskar R.B., Malavlya D. R., Roy A. K. and Kaushal P. 2002. Evaluation of exotic Trifolium accessions for disease incidence and resistance. Abstr. Nat. Symp. On Grassland and Fodder Research in the New Millennium held at IGFRI, Jhansi. Pp. 31-32.

Bhowal M., Cherian K. J. and Das L. (2011) Direct organogenesis in fodder crop Trifolium alexandrium L., Journal of Environmental Research And Development, Vol. 5 (4):892-897.

Chandra, A. (2011) Use of EST database markers from $M$. truncatula in the transferability to other forage legumes. J. Environ. Biol. 32, 347-354.

Chaudhry AR, Inam-ul-Haq and Nadeem Rehman A (1992) Cultural approach towards control of Berseem root rot, Pak, J. Agric. Science, 29 (1): 65-68.

Choo TM, Reinbergs E, Kasha KJ (1985) Use of haploids in breeding barley. Plant Breed Rev 3: 220-252 
Chowdhury J. B., Mehta R. K., Joshi A. B. 1966. Pollination in Berseem. Indian Journal of Genetics and Plant Breeding, 26 (1): 118-120.

Chowdhury, J. B., Mehta, R. K., and Joshi, A. B. 1966. Pollination in Berseem. Indian Jour. Genet. Plant Breed. 26: 118-120.

Das Gupta NC (1943) Green Berseem as a substitute for concentrates or economic feeding of dairy cattle. Indian journal of veterinary science and animal husbandry. 13:196-213.

Dhaliwal, J.S. and Atwal A.S. (1976). Note on the effect of air temperature, relative humidity and wind velocity on bees visiting Berseem at Ludhiana. Indian Journal of Agriculture Sciences, 46: 5051.

Dixit OP, U. P. Singh and J. N. Gupta (1989) Significance of Pollination in Seed Setting Efficiency of Berseem (Trifolium alexandrinum L.), Journal of Agronomy and Crop Science, 162(2): 93-96

Ellison NW, Liston A, Steiner JJ, Williams WM, Taylor NL (2006) Molecular phylogenetics of the clover genus (Trifolium-Leguminosae). Mol Phylog Evol 39:688-70.

Gupta, Pc; Karwasra, Sso, 1982: Epicoccum leaf spot-a new disease of Berseem Trifolium alexandrinum Egyptian clover. Indian phytopathology 35(3): 538539

Jobshy, Z.M., E.1. Syed, A. Rammah and MA. Satter, 1981. Pathogenicity and control of three fungi associated with damping off and root rot of Egyptian clover Trifolium alexandnnum, Res. Bull. No. 1674, p. 14.

Kaila V, V. K. Sood, H. K. Chaudhary, J. C. Bhandari, Archit Sood and R. K. Mittal (2009) Morphological and RAPD markers - mediated assessment of genetic diversity amongst various Trifolium species and identification of potential ideotypes for genetic upgradation of

Berseem under changed climate in midhills of north-west Himalayas. Indian J. Genet., 69(4): 1-6 (2009)
Kaur, A., Kaur, K.P., Kalia, A. et al., (2017). Generation of interspecific hybrids between Trifolium vesiculosum and $\mathrm{T}$. alexandrinum using embryo rescue Euphytica 213: 253 https://doi.org/10.1007/s10681-017-2042$\mathrm{x}$

Kaushal P, DR Malaviya, Roy AK, Aparna Tiwari, B Kumar (2005) Trifolium alexandrinum $\times \mathrm{T}$. resupinatum Interspecific Hybrids Developed through Embryo Rescue. Plant Cell Tissue and Organ Culture 83(2):137-144

Kaushal P, A. Tiwari, A.K. Roy, D.R. Malaviya and B. Kumar (2006) In vitro regeneration of Trifolium glomeratum. Biologia Plantarum 50 (4): 693-696

Kaushal P, D. R. Malaviya, A. K. Roy and B. Kumar (2004) In Vitro Response of Immature Zygotic Embryos of Trifolium alexandrinum (Egyptian clover), Plant Cell Biotechnology and Molecular Biology, 5(3-4): 109-114

Knight WE (1985) Miscellaneous annual clovers. In Taylor NL (edn) Clovers Science and Technology. Agron Monog 25:547-561

Kumar, B., Malaviya, D.R., Roy A.K. and Kaushal P. (2003). Protein profile and species relationship in Trifolium. Indian J. Genet., 63(1): 41-44.

Lange $O$ and MT Schifino-Wittmann (2000) Isozyme vtriation in wild and cultivated species of the genus Trifolium L. (Leguminosae). Ann. Bot. 86: 339-345.

Malaviya D.R. A. K. Roy P. Kaushal B. Kumar A. Tiwari C. Lorenzoni (2004) Development and characterization of interspecific hybrids of Trifolium alexandrinum $\mathrm{X}$ T-apertum using embryo rescue. Plant Breeding 123:536 - 542. DOI.10.1111/j.1439-0523.2004.01042.x

Malaviya DR, B. Kumar, A.K. Roy, P. Kaushal and Aparna Tiwari (2005). Estimation of variability of five enzyme systems among wild and cultivated species of Trifolium, Genetic Resources and Crop Evolution (2005). 52: 967-976

Malaviya DR, Roy AK, Aparna Tiwari, P 
Kaushal, B Kumar (2006) In vitro Callusing and Regeneration in Trifolium resupinatum-A Fodder Legume Cytologia 71(3):229-235. DOI10.1508/cytologia.71.229

Malaviya, D.R., Pandey, K.C., Roy, A.K. and Kaushal, P. (1999). Role of honey bees in seed setting of Egyptian clover. Crop Improvement, 26(2): 204-207.

Malaviya, D.R., Roy, A.K., Kaushal, P., Bhaskar, R.B. and Kumar B. (2004). Evaluation of Trifolium species for defining multiple use gene pool for tropical Trifolium species. Indian J. Genet., 64(3): 251-252

Mehta R., Swaminathan M. (1957) Studies on induced polyploids in forage crops. 1. Survey of previous work. Ind. J. Genet. PL Breed 17:27-57.

Narayanan, E. S., Sharma, P. L., Phadke, K. G. 1961. Studies on requirements of various crops for insect pollination - insect pollinators of erseem - Berseem clover (Trifolium alexandrinum) with particular reference to honey bees and their role in seed setting. Indian Bee Jour. 23(4/6): 23-30.

Pandey KC and Roy AK 2011.Forage Crops Varieties. IGFRI Jhansi (India).

Putiyevsky E, Katznelson J (1973) Cytogenetic studies in Trifolium spp. Related to Berseem. I. Intra- and inter-specific hybrid seed formation. Theor Appl Genet 43:351-358

Roy AK, Aparna Tiwari, DR Malaviya, P Kaushal, B Kumar (2005) Regeneration Efficiency in Trifolium apertum as Influenced by Explant Media Interaction. Cytologia 70(2):153-159

Roy AK, D R Malaviya, P Kaushal, A Chandra, U P Singh (2009) Descriptors for Tropical Forage Legume - Egyptian clover/Berseem Trifolium alexandrinum L., IGFRI, Jhansi

Roy AK, D. R. Malaviya and P. Kaushal (2005) Pollination behaviour among different breeding populations of Egyptian clover. Plant Breeding, 124 (2):171-175

Roy AK, D. R. Malaviya, P. Kaushal, B.
Kumar, A. Tiwari (2004). Interspecific hybridization of Trifolium alexandrinum with T. constantinopolitanum using embryo rescue. Plant Cell Rep, 22:705710

Roy AK, DR Malaviya and P Kaushal (2005) Pollination Berseem among different breeding populations of Egyptian clover. Plant Breeding 124: 171-175.

Roy AK, DR Malaviya, P Kaushal (2011) Generation of Interspecific Hybrids of Trifolium Using Embryo Rescue Techniques. Methods in molecular biology (Clifton, N.J.) 710:141-51. DOI10.1007/978-1-61737-988-8_12

Roy, A.K., Malaviya, D.R. and Kaushal, P. (2005). Pollination Berseem among different breeding populations of Egyptian clover. Plant Breeding, 124(2):171-175.

Roy, A.K., Malaviya, D.R., Kaushal, P., Chandra, A and Singh, U.P. (2009). Descriptors for tropical forage legume Egyptian clover (Trifolium alexandrinum L.), Indian Grasses and Forest Research Station, Jhansi, India.

SevaNayak D., Singh, T. and Radhakrishna A. (2017). Effect of drought stress on biomass and drought adaptive traits in Berseem (Trifoliumalexandrinum L.), National symposium "new directions in managing forage resources and livestock productivity in $21^{\text {st }}$ century: challenges and opportunity" P4-17

Shipra Agarwal, Bhupendra Singh, Alka and P Kumar. Salinity Tolerance of some cultivars of Berseem (Trifolium alexandrinum L.) during Germination and Early Seedling Growth. Vegetos. Vol. 23 (1): $63-82$ (2010)

Shukla GP and BD Patil (1985) Breeding Egyptian Cloler - A Review. Forage Research 11(1): 1-19.

Sidhu BS and PD Mehndiratta (1976) Genetic analysis of factors influencing forage yield Berseem. Indian J. Agric,:b, 46: 168-170.

Sikka S. M., Mehta R. K., Swaminathan M. S. (1959) Studies on Induced Polyploids in 
Forage Crops II. Colchicine Treatment Methods for Berseem and Senji. Indian Journal of Genetics and Plant Breeding, 19(1): 90-97

Singh, T., Malaviya, D. R. and Kaushal P (2015) Genetic analysis of some morphological traits in Egyptian clover (Trifolium alexandrinum L.) Sustainable use of grassland resources for forage production, biodiversity and environmental protection: Extended Abstracts $23^{\text {rd }}$ International Grassland Congress, Editors: A K Roy, R V Kumar, R K Agrawal, S K Mahanta, J B Singh, M M Das, K K Dwivedi, G. Prabhu, N. K. Shah. Paper ID: 1467

Singh, T., Radhakrishna, A., SevaNayak D. and Malaviya D.R. (2017). Identification and characterization of novel variability developed through wide hybridization in Egyptian clover (Trifolium alexandrinum L.), National symposium "new directions in managing forage resources and livestock productivity in $21^{\text {st }}$ century: challenges and opportunity" P2-24

Sohoo, M.S.; Beri, S.M.; Bhardwaj, B.L. (1985)

Radiation induced late flowering and high yielding mutant in Berseem (Trifolium alexandrinum L.). Journal of Nuclear Agriculture and Biology; v. 14(4) p. 136138

Taylor NL (1985) Clovers around the World. In TL Taylor (ed): Clover Science and Technology. Agron Monog 25:1-6
Verma P, A Chandra, AK Roy, DR Malaviya, P Kaushal, D Pandey, S Bhatia (2015) Development, characterization and crossspecies transferability of genomic SSR markers in Berseem (Trifolium alexandrinum L.), an important multi-cut annual forage legume. Mol Breeding (2015) 35:23

Verma, JS and Mishra SN, 1995. Advances in Forage Improvement in Upper Gangetic Plains. In: New Vistas in Forage Production. Hazra CR, Mishri B (eds). All India Coordinated Project for Research on Forage Crops, Indian Grassland and Fodder Research Institute Jhansi-284003 (U P), India, pp 83-96.

Zayed E.M., Magda I. Soliman, G. A. Ramadan and M. M. Tarrad (2010) Molecular characterization of two cultivars of Egyptian clover (Trifolium alexandrinum L.). Range Mgmt. and Agroforestry 31 (2): 140-143, 2010

Zohary M (1972) A revision of the species of Trifolium sect. Trifolium (Leguminosae), II Taxonomic treatments. Candollea 27:99-158

Zohary M (1972) Origins and evolution in the genus Trifolium. Bot Not 125:501-511

Zohary M, Heller D (1984) The genus Trifolium. The Israel Academy of Sciences and Humanities, Jerusalem.

\section{How to cite this article:}

Tejveer Singh, A. Radhakrishna, D. Seva Nayak and Malaviya, D.R. 2019. Genetic Improvement of Berseem (Trifolium alexandrinum) in India: Current Status and Prospects. Int.J.Curr.Microbiol.App.Sci. 8(01): 3028-3036. doi: https://doi.org/10.20546/ijcmas.2019.801.322 